\title{
LOS CONTRARREVOLUCIONARIOS Y EL ISLAM: UN ANÁLISIS DEL PENSAMIENTO ANTIISLÁMICO DE LOUIS DE BONALD
}

\author{
THE COUNTER-REVOLUTIONARIES AND ISLAM: \\ AN ANALYSIS OF LOUIS DE BONALD'S \\ ANTI-ISLAMIC THOUGHT
}

\author{
Fernando Bravo López \\ Universitat Pompeu Fabra
}

Entregado el 5-10-2015 y aceptado el 2-4-2016

Resumen: Los contrarrevolucionarios franceses de finales del XVIII y principios del XIX situaron a la Ilustración como objetivo principal de sus críticas. Según su punto de vista, ésta había socavado las bases religiosas sobre las que se asentaba la sociedad del Antiguo Régimen, lo que había llevado, en último término, a la Revolución.

Entre los males que se achacaban a los philosophes estaba el de haber sentido una «predilección» hacia el islam, debido a su empeño por acabar con los fundamentos cristianos de la sociedad. Por ello, los contrarrevolucionarios trataron de luchar contra las «falsedades» difundidas por los ilustrados acerca del islam.

En este artículo se analizarán las ideas antiislámicas de Louis de Bonald, uno de los principales pensadores contrarrevolucionarios. Se verá que, para restaurar la «verdad» contra las «falsedades» ilustradas, Bonald recurrió a la visión del islam transmitida por la tradición antiislámica cristiana; pero que, a la vez, introdujo novedades influidas, paradójicamente, por el pensamiento ilustrado. De esta forma, manteniendo intactos los fundamentos de la tradición antiislámica, introdujo novedades discursivas que ayudaron a adecuarla a un nuevo contexto, preparándola para el periodo colonial.

Palabras clave: Contrarrevolución; Louis de Bonald (1754-1840); Islam; Musulmanes; Tradición antiislámica; Islamofobia. 


\begin{abstract}
Enlightenment was the main ideological target of late eighteenth and early nineteenth century French counter-revolutionaries. They considered that it had undermined the religious foundations of the Ancien Régime, leading, ultimately, to the Revolution.

Among the evils the counter-revolutionaries pinned on the philosophes was their «predilection» for Islam, in line with their alleged desire to destroy the Christian foundations of society. It was for this reason that the counter-revolutionaries took it upon themselves to combat the «falsehoods» concerning Islam spread by the philosophes.

In this article, we will analyse Louis de Bonald's take on Islam. Bonald was one of the main counter-revolutionary thinkers and he was determined to dissipate the «falsehoods» spread by the philosophes and restore the «truth». To this end, Bonald availed himself of the view upheld by the anti-Islamic Christian tradition, but he also introduced novelties influenced - paradoxically - by the Enlightened thought. Thus, while maintaining intact the foundations of the antiIslamic tradition, Bonald introduced discursive innovations that helped the antiIslamic tradition to adapt to a new context, preparing it for the Colonial period.
\end{abstract}

Key words: Counter-revolution; Louis de Bonald (1754-1840); Islam; Muslims; Anti-Islamic tradition; Islamophobia. 
Peut-être nos descendants sont-ils destinés à voir, au grand scandele de la philosophie moderne, de nouvelles croisades de Chrétiens.

Louis de Bonald ${ }^{1}$

\section{Introducción: los contrarrevolucionarios y el islam}

Cuando los historiadores se han enfrentado al estudio de la imagen del islam en la Europa del siglo XVIII su atención se ha centrado principalmente en la visión de los filósofos ilustrados. De manera secundaria, la investigación se ha dirigido hacia el estudio de la representación del islam y del llamado «mundo islámico» en el temprano orientalismo académico, en la literatura de viajes y de ficción, en la pintura, la música y el resto de las artes. ${ }^{2} \mathrm{Si}$

${ }^{1}$ Louis de Bonald, Oeuvres complètes de M. de Bonald, 3 vols., J.-P. Migne, París, 1859 , vol. 2 , p. 470.

2 Sobre la imagen ilustrada del islam véase Albert Hourani, «Islam and the philosophers of History», Middle Eastern Studies, vol. 3, n. ${ }^{\circ} 3$ (1967), pp. 206-268; Georges H. Bousquet, «Voltaire et l'Islam», Studia Islamica, n. 28 (1968), pp. 109-126; Gavad Hadidi, Voltaire et l'Islam, Publications Orientalistes de France, París, 1974; Bernard Lewis, «Gibbon on Muhammad», Daedalus, vol. 105, n. 3 (1976), pp. 89-101; Maxime Rodinson, La fascinación del islam, Júcar, Madrid, 1989, pp. 71-77; Hichem Djaï, Europa y el Islam, Libertarias, Madrid, 1990, pp. 45-55; Albert Hourani, Islam in European thought, Cambridge University Press, Cambridge y Nueva York, 1991, pp. 10-15; P.M. Holt, «The study of islam in seventeenth-and eighteenth-century England», Journal of Early Modern History, vol. 2, n. 2 (1998), pp. 113-123; Asli Çirakman, «From tyranny to despotism: The Enlightenment's unenlightened image of the Turks», International Journal of Middle East Studies, vol. 33, n. ${ }^{\circ} 1$ (2001), pp. 49-68; Sadek Neaimi, L'Islam au siècle des Lumières, L'Harmattan, París, 2003; Rebecca Joubin, The «Oriental Other» and cultural self-criticism in the eighteenth-century French Enlightenment, Tesis doctoral, Columbia University, Nueva York, 2004; Dominique Carnoy-Torabi, «Regards sur l'islam, de l'âge classique aux Lumières», y Henry Laurens, «L'islam dans la pensée française, des Lumières à la III ${ }^{\mathrm{e}}$ République», ambos en Mohammed Arkoun y Jacques Le Goff (eds.), Histoire de l'islam et des musulmans en France du Moyen Âge à nos jours, Albin Michel, París, 2006, pp. 436-474 y 483-499; Jonathan I. Israel, Enlightenment contested, Oxford University Press, Oxford y Nueva York, 2006, pp. 615-639; Gerard Wiegers, «Islam and radical Enlightenment», Journal of the Dutch-Flemish Levinas Society, vol. XVI, (2011), pp. 41-50; Fernando Bravo López, En casa ajena: bases intelectuales del antisemitismo y la islamofobia, Ed. Bellaterra, Barcelona, 2012, pp. 208-213; Humberto García, Islam and the English Enlightenment, 1670-1840, The Johns Hopkins University Press, Baltimore, 2012. Sobre el orientalismo académico y la imagen del islam en las letras y las artes de la época véase, por ejemplo, Pierre Martino, L'Orient dans la littérature française au XVII et au XVIII ${ }^{e}$ siècle, Hachette et $\mathrm{C}^{\mathrm{ie}}$, París, 1906; James Thompson, The East: imagined, experienced, 
la Ilustración ha atraído de tal forma la atención de los analistas se debe, sin duda, a la influencia que posteriormente autores como Montesquieu, Voltaire, Rousseau, Kant o Hume han tenido en la cultura europea. Esa influencia posterior ha hecho que el siglo XVIII termine confundiéndose en su totalidad con la Ilustración, olvidándose a veces que los ilustrados no sólo compartieron escenario con autores más tradicionalistas, sino que se vieron combatidos incansablemente por éstos - ayudados incluso por el aparato del Estado - , llegando a verse perseguidos y marginados. En realidad, la Ilustración es tan del siglo XVIII como aquellos que la combatían. ${ }^{3}$

Como consecuencia de esa tendencia a confundir el siglo XVIII con la Ilustración, también en los estudios sobre la imagen del islam en Europa se ha tendido a confundir la visión de los ilustrados con la visión del siglo XVIII. Maxime Rodinson, por ejemplo, exagerando la simpatía que aquéllos mostraron hacia el islam, llegó al extremo de afirmar que «el siglo XVIII vio ciertamente al Oriente musulmán con ojos fraternales y comprensivos»; y, de manera semejante, Hichem Djaït consideró que «el siglo XVIII europeo se caracterizó por un profundo deseo de comprensión del islam». ${ }^{4}$ Ambos autores olvidaban que, como señaló Albert Hourani, la visión ilustrada del islam tuvo poco efecto en los autores que se mantuvieron más fieles a la ortodoxia cristiana. ${ }^{5}$

Si la Ilustración en su totalidad fue combatida incansablemente durante el siglo XVIII por los autores más apegados al dogma de la Iglesia, su visión del islam no lo fue menos. Trataron de luchar contra los «erro-

remembered: Orientalist nineteenth century painting, National Gallery of Ireland, Dublin, 1988; Edward W. Said, Culture and imperialism, Vintage, London, 1994; John M. MacKenzie, Orientalism: history, theory, and the arts, Manchester University Press, Manchester, 1995; Alexander L. Macfie, Orientalism, Longman, Londres, 2002, pp. 25-49; Edward W. Said, Orientalismo, 2. a ed., Debolsillo, Barcelona, 2003, pp. 112-128, 175-183; Zachary Lockman, Contending visions of the Middle East, Cambridge University Press, Cambridge y Nueva York, 2004, pp. 66-78; Suzanne Marchand, German Orientalism in the age of empire, Cambridge University Press, Cambridge y Nueva York, 2009, pp. 15-52; Srinivas Aravamudan, Enlightenment Orientalism, The University of Chicago Press, Chicago y Londres, 2012.

${ }^{3}$ Sobre la oposición a la Ilustración véase Darrin M. McMahon, Enemies of the Enlightenment: the French counter-Enlightenment and the making of Modernity, Oxford University Press, Oxford y Nueva York, 2001; Graeme Garrad, Counter-Enlightenments: from the eighteenth century to the present, Routledge, Abingdon, 2006; Zeev Sternhell, Les antiLumières: du XVIIIe siècle à la guerre froide, Fayard, París, 2006.

${ }^{4}$ Rodinson, La fascinación del islam, p. 74; Djaï, Europa y el Islam, p. 41.

5 Hourani, «Islam and the philosophers of History». 
res» divulgados por los filósofos ilustrados, esforzándose por sostener la tradición antiislámica que había pervivido en Europa desde la Edad Media. Sin embargo, pretendieron hacerlo - y en esto prefiguraron a los autores contrarrevolucionarios posteriores - a partir de argumentos racionales, no apelando a la autoridad de la tradición. No obstante, a pesar de sus pretensiones, y precisamente por la autoridad que conservaba la tradición en esos sectores de la sociedad, no pudieron dejar de remitirse a ella. Terminaban, así, esgrimiendo lo que ellos consideraban la «verdad» - la basada en la tradición cristiana - contra las «falsedades» del islam y los ilustrados. A las afirmaciones de los ilustrados sobre el Corán contraponían la autoridad de la Biblia. A los elogios que los ilustrados habían dirigido a Mahoma contraponían la imagen que la tradición cristiana había construido de él. El texto que el abate Claude-François Nonnotte compuso para contradecir la visión que Voltaire había transmitido del profeta del islam es un buen ejemplo de esta forma de proceder. ${ }^{6}$

Los autores contrarrevolucionarios de finales del siglo XVIII y principios del XIX continuaron esta tendencia, llevándola un paso más allá en su intento de combatir a la Ilustración con las armas de la razón. También éstos, en su enmienda a la totalidad de la Ilustración, incluyeron una crítica feroz a la imagen que, según ellos, ésta había transmitido del islam. A su juicio, la tímida apertura hacia el islam que realizaron los autores ilustrados resultaba un exceso escandaloso, y la interpretaron como una muestra de «predilección», como diría Louis de Bonald. ${ }^{7}$ Para ellos, por el contrario, el Mal debía mostrarse absolutamente maligno, no podía aparecer atenuado, no podía tener aspectos positivos, por minúsculos que estos fueran. Los ilustrados, al rescatar como positivos algunos aspectos de la personalidad de Mahoma, alguna de las enseñanzas del Corán, algunas características de los pueblos árabe, turco o persa, estaban negando el carácter maligno del islam; lo estaban convirtiendo en algo humano, con aspectos positivos y negativos, y eso resultaba inaceptable. Devolver al islam su «verdadero» carácter, acabar con las «mentiras» diseminadas por los ilustrados, será una de las tareas que algunos pensadores contrarrevolucionarios se impondrán a sí mismos, siguiendo la línea abierta por los autores antiilustrados anteriores.

\footnotetext{
${ }^{6}$ Claude-François Nonnotte, Erreurs de Voltaire, 3 vols., nouvelle édition augmentée, Méquignon junior, París, 1822 [1. a ed. 1762], vol. 1, pp. 52-57.

7 Bonald, Oeuvres complètes, vol. 2, p. 395.
} 
Desgraciadamente, los estudios que hasta la fecha se han dedicado a estudiar esta otra visión del islam han sido escasos. Sólo François-René de Chateaubriand (1768-1848) ha recibido alguna atención, especialmente su Itinéraire de Paris à Jérusalem (1811), en donde su actitud antiislámica quedaba plenamente evidenciada. Así, por ejemplo, con respecto al Corán y las enseñanzas islámicas, Chateaubriand afirmaba que «no hay en el libro de Mahoma ni principio de civilización, ni precepto que pueda elevar el carácter: ese libro no predica ni el odio a la tiranía, ni el amor a la libertad». Y más adelante, con respecto a las cruzadas, sostenía, contradiciendo abiertamente la opinión de los ilustrados - que las habían criticado con dureza-, que en éstas se trataba «de saber quién prevalecería sobre la tierra, un culto enemigo de la civilización, favorable por sistema a la ignorancia, al despotismo, al esclavismo, o un culto que ha hecho revivir en los modernos el genio de la docta antigüedad, y abolido la servidumbre». En definitiva, para Chateaubriand, «el espíritu del mahometismo es la persecución y la conquista; el Evangelio al contrario no predica más que la tolerancia y la paz». 8

Otros autores contrarrevolucionarios, como Joseph de Maistre (17531821) o Louis de Bonald (1754-1840), no han recibido atención alguna, a pesar de la importancia que han tenido dentro de la historia del pensamiento europeo contemporáneo. Alexandre Koyré, por ejemplo, sostiene que en Bonald se encuentra la base del pensamiento antidemocrático del siglo XIX. Algunos autores han ido más allá al considerar incluso que en los dos autores se encuentran las raíces del pensamiento fascista, ${ }^{9}$ algo que otros han considerado «una acusación estrafalaria». ${ }^{10}$ En cualquier caso, tanto Maistre como Bonald contribuyeron de forma determinante a la construcción del discurso reaccionario, antiilustrado, antiliberal, antidemocrático y, en una palabra, contrarrevolucionario, de los siglos XIX y XX.

${ }^{8}$ François-René de Chateaubriand, Oeuvres complètes de M. le vicomte de Chateaubriand, 32 vols., Pourrat Fréres, París, 1836-1839, vol. 9, pp. 193-194, vol. 10, pp. 196197. Sobre la actitud de Chateaubriand con respecto al islam, y el mundo árabe en particular, véase Said, Orientalismo, pp. 235-241; Tzvetan Todorov, Nosotros y los otros: reflexión sobre la diversidad humana, Siglo XXI, México; Buenos Aires, 2009, pp. 324-350.

${ }_{9}$ Isaiah Berlin, The crooked timber of humanity: chapters in the history of ideas, John Murray, Londres, 1990, pp. 91-174; David Klinck, The French counterrevolutionary theorist Louis de Bonald (1754-1840), Wien, París, 1996.

${ }_{10}$ Michael Burleigh, Poder terrenal: religión y política en Europa, Taurus, Madrid, 2005, pp. 152-166. Burleigh se refiere en concreto a las interpretaciones de Isaiah Berlin con respecto a Maistre. 
Por lo que respecta a Maistre, esta falta de interés puede deberse al poco espacio que este autor dedicó al islam en sus escritos. Sin embargo, no dejó de encontrar el momento para manifestar claramente cuáles eran sus ideas al respecto. En su obra Del Papa (1819), mientras añadía a las innumerables virtudes del papado el «habernos salvado del creciente», ${ }^{11}$ aseguraba que, de no haberse dado el Gran Cisma entre la Iglesia de occidente y la de oriente, las invasiones árabes de los siglos VII y VIII se habrían impedido, y con ello «las ciencias, las artes, la civilización, ilustrarían esos famosos países de Asia, que una vez fueron el jardín del universo, y que hoy están despoblados, dejados a la ignorancia, al despotismo, a la peste, a todo género de embrutecimiento». El islam había convertido el mundo ocupado por él en un lugar horrible, y los musulmanes, al permanecer ajenos a la verdadera fe, se habían visto abocados a la perdición, no sólo espiritual, sino también material.

La diferencia confesional hacía de los musulmanes seres totalmente diferentes a «nosotros» e incapaces de cambiar a lo largo del tiempo. ${ }^{12}$ Esa radical y absoluta alteridad, irreductible precisamente por la incapacidad de los musulmanes para cambiar con el tiempo, los convertía en acérrimos y eternos enemigos de los cristianos. Y ese antagonismo esencial, el mismo que existía entre el Bien y el Mal, hacía que la guerra entre cristianos y musulmanes fuera inevitable y necesaria. De ese conflicto sólo uno de los bandos podría salir victorioso y seguir existiendo. El otro debía someterse o ser destruido:

El discípulo de Mahoma no se nos parece de ninguna manera: es extranjero, no puede asociarse ni mezclarse con nosotros. ¡ Ved a los turcos! Espectadores desdeñosos y arrogantes de nuestra civilización, de nuestras artes, de nuestras ciencias; enemigos mortales de nuestra religión, son hoy lo que eran en 1454; un campamento de tártaros, asentado sobre tierra europea. La guerra entre nosotros es natural, y la paz forzada. Cuando el cristiano y el musulmán entran en contacto, uno de los dos debe someterse o perecer. ${ }^{13}$

11 Joseph de Maistre, Du Pape, 9. a ed., J. B. Pélagaud et Ce, Lyon, 1853 [1. a ed. 1819], p. 390 .

${ }^{12}$ La incapacidad para el cambio de los pueblos «orientales», y de los musulmanes en particular, es, según Edward Said, uno de los «dogmas» centrales del orientalismo; véase Said, Orientalismo, p. 305.

13 Maistre, Du Pape, p. 391, cursivas en el original. 
De tal manera, cualquier guerra contra un enemigo identificable como islámico quedaba totalmente legitimada: era una cuestión inevitable, resultante de la propia naturaleza antagónica de ambos credos, de su propia esencia. Se trataba, en definitiva, de una consecuencia necesaria del antagonismo eterno entre el Bien y el Mal. Por tanto, o se luchaba contra el islam o la humanidad perecería. Las cruzadas, de hecho, no habían sido sino una lucha por la propia existencia de la «raza humana»: «sin esas guerras santas, toda la raza humana estaría quizás todavía hoy degradada hasta los más profundos abismos de la servidumbre y la barbarie». ${ }^{14}$ De modo que sólo cabían dos posibilidades: o la lucha contra el islam, o la servidumbre y la barbarie. Esta era la visión de Joseph de Maistre.

La visión de Louis de Bonald, como se verá, no era muy diferente. A lo largo de las siguientes páginas se analizará más detenidamente su caso. Se verá que su actitud hacia el islam fue, por un lado, una respuesta abiertamente hostil a la supuesta simpatía que los filósofos ilustrados mostraron hacia esa religión y esa «civilización». Y, por otro lado, se verá que Bonald no se limitó a retomar las viejas acusaciones mantenidas por la tradición antimusulmana premoderna, sino que actualizó esas acusaciones haciendo suyos buena parte del vocabulario y de los argumentos ilustrados, si bien dándoles un sentido bien diferente. Se verá, por tanto, cómo a través de autores como Bonald la tradición antimusulmana se mantiene intacta en lo más importante, pero también se transforma, se actualiza, incorporando un nuevo vocabulario que en principio resultaba secular, proveniente de la filosofía laica del XVIII y ajeno a la tradición teológica cristiana. El caso de Bonald nos servirá, por tanto, para mostrar cómo existe efectivamente una continuidad dentro de la tradición antimusulmana hasta el periodo contemporáneo, y cómo esta tradición, a la vez, ha ido introduciendo cambios que le han permitido actualizarse y sobrevivir. ${ }^{15}$

En lo que sigue, tras realizar una breve exposición del pensamiento de Louis de Bonald, nos centraremos en el análisis de la imagen del islam que este autor transmitió en sus obras. Para ello, hemos seleccionado tres textos escritos en contextos históricos bien diferentes, en un periodo que abarca más de veinte años. El primero de los textos fue escrito en los años

14 Ibid., p. 393.

15 Sobre el debate en torno a la continuidad y el cambio en la tradición antimusulmana véase Fernando Bravo López, «Islamofobia: acerca de la continuidad y el cambio en la tradición antimusulmana», Historia Social, n. 75 (2013), pp. 41-61. 
del Directorio, mientras Bonald estaba aún en su exilio de Heidelberg. El segundo se escribió pocos años después, durante el Consulado, cuando Napoleón Bonaparte estaba iniciando su carrera hacia la monopolización del poder. Finalmente, el tercero se escribió en los años veinte, en pleno reinado de Luis XVIII. Los tres tienen, además, un carácter diferente. Mientras el primero es un texto escrito por el Bonald filósofo preocupado por cuestiones transcendentes, los dos últimos son textos escritos por el Bonald publicista preocupado por los acontecimientos políticos que vive. Sin embargo, a pesar de las diferencias y del tiempo transcurrido, una misma imagen del islam pervive, una misma preocupación y un mismo deseo de acabar con él.

\section{El pensamiento de Louis de Bonald}

El proceso revolucionario iniciado en 1789 produjo, evidentemente, una gran conmoción en la sociedad francesa. El nuevo orden, que se consolidaría en 1792 con la proclamación de la República, inspiró muchos apoyos, pero también una gran oposición. Dentro de los opositores hubo quien, desde el principio, quiso retornar al punto de partida, devolver las cosas a su «estado natural» y reinstaurar el Antiguo Régimen. Entre los sectores que más vehementemente se opusieron al proceso revolucionario estuvieron aquellos que, a causa de él, perdieron sus privilegios ancestrales: la nobleza y el clero. Si bien hubo nobles y clérigos que participaron en la causa revolucionaria y apoyaron la labor de la Asamblea Nacional, en general, lo que en adelante se conocería como la contrarrevolución, ${ }^{16}$ se nutrió sobre todo de estos dos sectores sociales.

La promulgación de la Constitución Civil del Clero en 1790 fue un paso muy importante que contribuyó a echar a una parte significativa de la Iglesia católica en brazos de la contrarrevolución. Una vez unidas Iglesia y nobleza en una causa común, sólo les faltaba una ideología definida que les permitiera legitimar su abierta oposición. Como ha señalado Peter McPhee, «la implicación del clero refractario en la contrarrevolución y la consiguiente proscripción y descristianización durante el Terror aca-

\footnotetext{
${ }^{16}$ Aunque, como se sabe, durante el Terror el término empezó a tener un significado excesivamente amplio. Véase, por ejemplo, en la Ley de 10 de junio de 1794 en Peter McPhee, La Revolución Francesa, 1789-1799: una nueva historia, 2. ${ }^{a}$ ed., Crítica, Barcelona, 2009, p. 181.
} 
baría uniendo a Iglesia y monarquía en una ideología realista de derechas, uno de los principales movimientos políticos de Francia de los 150 años siguientes.» ${ }^{17} \mathrm{Y}$ fue en el diseño y difusión de esa ideología donde autores como Joseph de Maistre o Louis de Bonald tuvieron una importancia determinante.

Louis de Bonald fue uno de los miles de émigrés - se estima que hacia 1799 eran entre 120.000 y $150.000^{18}$ - que abandonaron Francia huyendo de la Revolución para, en muchos casos, sumarse a las filas de la contrarrevolución en el extranjero. Después de haber apoyado el proceso revolucionario durante los primeros dos años, su oposición a la Constitución Civil del Clero le llevó a dimitir de sus puestos como representante político de su Departamento y, finalmente, en 1791, al exilio en Heidelberg. Fue allí donde empezó su labor como teórico de la contrarrevolución. En 1796 publicó la que sería su principal obra, Théorie du pouvoir politique et religieux, en donde ponía las bases de su enmienda a la totalidad de la Ilustración, empezando con las ideas sobre el gobierno de Montesquieu y Rousseau, la separación de poderes, la soberanía popular y las teorías contractualistas de la sociedad y el gobierno.

Tras el establecimiento del Directorio, Bonald decidió volver clandestinamente a Francia (1797). A partir de ese momento se convirtió en un prolífico publicista de la causa monárquica, pero también continuó su trabajo como teórico de la contrarrevolución. Tras el golpe de 18 Brumario (9 de noviembre de 1799), y ya consolidado el Consulado, Bonald publicó sus demás obras importantes: Essai analytique sur les lois naturelles de l'ordre social (1800), Du Divorce (1801) y Législation primitive (1802). Sin embargo, tras unas primeras expectativas favorables, pronto se desilusionó con Napoleón y optó por apartarse de la vida pública, hasta la caída del emperador y la Restauración borbónica en 1815.

Con el nuevo gobierno monárquico, Bonald adquirió otra vez protagonismo como defensor de la causa ultramonárquica y papal. Fue diputado entre 1815 y 1821, nombrado miembro de la Academia Francesa en 1816, ministro de Estado y censor en 1821, y, finalmente, par de Francia - con el título de vizconde - en 1823. A pesar de su nuevo estatus, debido a las ideas absolutistas que defendía, la monarquía parlamentaria adoptada por la Restauración y la Monarquía de Julio le resultó decepcionante. Tras la

17 Ibid., p. 214.

18 Jocelyn Hunt, The French Revolution, Routledge, Londres y Nueva York, 1998, p. 77. 
Revolución de 1830 , decidió abandonar la política y retirarse a sus tierras de Millau, donde murió diez años después. ${ }^{19}$

El pensamiento de Bonald se construye en directa oposición a la Ilustración - heredera directa, a su juicio, de la Reforma protestante-, en la cual encuentra la causa principal de la Revolución. ${ }^{20}$ Según él, si el caos y el desastre provocados por la Revolución eran el producto directo de las ideas ilustradas, cabía colegir que éstas no podían estar más equivocadas, pues su fracaso era obvio. Desde su punto de vista, ese fracaso no era difícil de explicar: el hombre había dado la espalda a Dios, había destruido el orden instituido por él rebelándose contra sus señores legítimos, y la consecuencia lógica había sido el caos más absoluto. Por lo tanto, sólo cuando las bases ideológicas de la Revolución fueran eliminadas, sólo cuando el gobierno legítimo sancionado por Dios volviera a regir los des-

19 Sobre la vida de Bonald, véase Bonald, Oeuvres complètes, vol. 1, pp. v-xxviii; Martin Simpson, «Bonald, Louis de (1754-1840)», en Gregory Claeys (ed.), Encylopedia of nineteenth-century thought, Routledge, Abingdon y Nueva York, 2005, pp. 80-84; Robert Wokler, «Bonald, Louis de», en John Merriman y Jay Winter (eds.), Europe: 1789 to 1914. Encyclopedia of the age of industry and empire, 5 vols., Thomson Gale, Detroit, Nueva York, etc., 2006, vol. 1, pp. 268-269.

${ }^{20}$ Sobre el pensamiento de Bonald véase Alexandre Koyré, «Louis de Bonald», Journal of the History of Ideas, vol. 7, n. ${ }^{\circ} 1$ (1946), pp. 56-73; Jacques Godechot, La contre-révolution: doctrine et action, 1789-1804, PUF, París, 1961, pp. 93 y ss; Jules Gritti, Bonald, la Révolution française et le réveil religieux, Bloud \& Gay, Paris, 1962; Stephen Holmes, «Two concepts of legitimacy: France after the Revolution», Political Theory, vol. 10, n. 2 (1982), pp. 165-183; W. Jay Reedy, «Language, counter-revolution and the "two cultures": Bonald's traditionalist scientism», Journal of the History of Ideas, vol. 44, n. 4 (1983), pp. 579-597; Louis de Bonald, Teoría del poder político y religioso, Estudio preliminar y selección de Colette Capitan, presentación y traducción de Julián Morales, Tecnos, Madrid, 1988, pp. XV-XXIV; Luis F. Múgica, Tradición y revolución: filosofía y sociedad en el pensamiento de Louis de Bonald, EUNSA, Pamplona, 1988; Klinck, The French counterrevolutionary theorist; Michel Toda, Louis de Bonald: théoricien de la contre-révolution, Clovis, Étampes, 1997; Philippe Nemo, Histoire des idées politiques aux temps modernes et contemporains, PUF, París, 2002, pp. 1052-1062; Simpson, «Bonald, Louis de (1754-1840)»; Joan Antón y Marco Esteban, «Capítulo VIII: Pensamiento contrarrevolucionario (de Maistre a Maurras)», en Joan Antón (ed.), Ideologías y movimientos políticos contemporáneos, Tecnos, Madrid, 2006, pp. 199-211; Wokler, «Bonald, Louis de». Durante el franquismo la figura de Bonald disfrutó en España de gran atención, por razones que parecen obvias; véase, por ejemplo: Leopoldo E. Palacios, «Bonald o la constitución natural de las sociedades», Revista de Estudios Políticos, n. 45 (1949), pp. 55 102; Id., «La ideología de Bonald», Actas del Primer Congreso Nacional de Filosofía, 3 vols., Universidad Nacional de Cuyo, Mendoza, 1950, vol. 3, pp. 1728-1734; Salvador Pons, La figura política del vizconde de Bonald, Ateneo, Madrid, 1954. 
tinos de Francia, volvería el orden. Así, Bonald sentenció en una famosa frase que «la revolución francesa empezó con la Declaración de los Derechos del Hombre; terminará sólo con la Declaración de los Derechos de Dios». ${ }^{21}$

Bonald consideraba que el error fundamental de los philosophes se encontraba en su concepción del hombre, en su identificación del hombre salvaje, alejado de la sociedad, con el hombre en estado de naturaleza, lo que les llevó a su idea de la existencia de un «contrato social» sobre el que se basaba la vida en sociedad. El error que subyacía en la concepción contractual de la sociedad era, en definitiva, una doctrina individualista de la naturaleza humana. Para Bonald, sin embargo, estas ideas carecían de sentido. Según él, para que hubiera un contrato, debía existir previamente una sociedad, ya que, para establecerlo, era necesario un hombre pensante. Para que ese hombre existiera era necesaria, a su vez, una lengua sobre la que basar el pensamiento; y la lengua era una capacidad social, luego no era posible un hombre, como ser racional, ajeno a la sociedad. Por lo tanto, el hombre en estado de naturaleza sólo podía ser un hombre en sociedad.

Evidentemente, en el origen de la sociedad estaba Dios mismo, quien había dado al hombre el lenguaje y, por lo tanto, la capacidad para pensar. Pero hablar de sociedad en lugar de hablar directamente de Dios - cosa de la que tampoco se privaba - permitía a Bonald recurrir a conceptos seculares en lugar de teológicos, secularizar en cierta medida su discurso, y dotarlo de una pátina de filosofismo. Como han señalado Joan Antón y Marco Esteban, el pensamiento contrarrevolucionario se construyó sobre las ruinas del viejo pensamiento reaccionario, pero «el nuevo paradigma revolucionario fue tan potente que pronto se convirtió en hegemónico». Para sobrevivir, el pensamiento reaccionario tuvo que cambiar, adaptarse al nuevo paradigma, y para ello tuvo que hacerlo «adoptando y mejorando las armas y técnicas que posibilitaron el triunfo de los vencedores». Se trataba de combatir las ideas ilustradas haciendo uso de sus propias armas, las del razonamiento filosófico, adoptando la forma, la terminología y el estilo - no obviamente el contenido - del discurso ilustrado, y volviendo contra él sus propias palabras. ${ }^{22}$ No en vano, Bonald colocó en la portada de su primera obra,

21 Bonald, Oeuvres complètes, vol. 1, p. 1133.

22 Antón y Esteban, «Pensamiento contrarrevolucionario». 
Théorie du pouvoir, una cita de El Contrato Social, ${ }^{23}$ con la que, evidentemente, quería volver en contra de los revolucionarios las palabras de uno de sus filósofos de referencia.

Bonald, en efecto, conocía muy bien el estilo de los filósofos ilustrados, así como sus obras más importantes, las cuales citaba en innumerables ocasiones. Esa familiaridad con las obras de los ilustrados es lo que le permitió dar a sus trabajos un aspecto filosófico y secularizar su lenguaje, pero manteniendo intacto el fondo del argumento teocrático: que era Dios el que conformaba y ordenaba la sociedad y cualquier revuelta contra lo establecido por la tradición era una revuelta contra Dios y estaba, por tanto, abocada al fracaso, al caos y, en último término, al castigo divino.

Si era Dios el que daba forma y ordenaba la sociedad instituyendo el poder legítimo, la religión era, en consecuencia, su verdadera constitución:

La religión es la razón de toda sociedad, puesto que fuera de ella no se puede encontrar la razón de ningún poder, ni ningunos deberes. La religión es por tanto la constitución fundamental de todo estado de sociedad. $^{24}$

De ahí se deducía la necesaria e indisoluble unión entre lo político y lo religioso en la sociedad, y también que no podía haber verdadera sociedad fuera de la Iglesia católica, el único y verdadero vínculo entre Dios y la sociedad. De esa mediación dependía la existencia de la sociedad misma, y del hombre tal y como lo entendía Bonald. Cualquier intento de construir una sociedad al margen de esa mediación conllevaba el fracaso y el caos.

La instauración de un poder político sin la sanción divina era sólo despotismo, y, por lo tanto, el gobierno republicano, paladín de la libertad y la igualdad, era, en realidad, despótico, y sus ciudadanos, esclavos. La monarquía absoluta, por el contrario, era la única forma de gobierno por la que era posible alcanzar la libertad, la verdadera libertad, la que consis-

${ }^{23}$ Hasta donde sabemos, la cita sólo aparece en la primera edición: Louis de Bonald, Théorie du pouvoir politique et religieux, 3 vols., s.n., Constance, 1796. Bonald se permitió truncar la cita, dando así al texto un sentido diferente. La cita original se encuentra en Jean-Jacques Rousseau, Du contrat social ou principes du droit politique, Marc Michel Rey, Amsterdam, 1762, pp. 115-116.

24 Bonald, Oeuvres complètes, vol. 1, p. 1260. 
tía en la facultad de actuar conforme a las leyes de la naturaleza. La unión entre la monarquía absoluta y la Iglesia católica daba como fruto la sociedad perfecta; y según Bonald, el ser humano sólo podía ser verdaderamente libre y feliz cuando vivía en una sociedad perfecta de ese tipo, sometido a la voluntad del rey y de la Iglesia.

De estas ideas sacaba Bonald unas conclusiones lógicas acerca de la necesidad de preservación de un orden social que era, en su opinión, de origen divino, y hacía del ser humano lo que era. Era necesario un estricto sistema de control social, un sistema de censura e intolerancia institucionalizada, que impidiera las innovaciones que pusieran en peligro el orden establecido por Dios.

Puesto que, como hemos visto, la capacidad de razonar había sido dada al hombre por Dios, la Razón no podía entrar en contradicción con la Revelación, la verdad de la una y de la otra debían coincidir por fuerza, puesto que su origen era el mismo: Dios. La Verdad, por tanto, según Bonald, era aquello que había sido transmitido al hombre por Dios y había sido conservado por la tradición. Por lo tanto, cualquier intento por parte del hombre de someter la tradición a la crítica intelectual estaba abocada al fracaso y a causar grandes males. Era un acto de rebelión contra la sociedad y contra Dios, y como tal debía ser perseguido. Habiendo fijado Dios cuál era el orden natural de las cosas, cómo debía formarse la sociedad, quién debía ostentar el poder legítimo y cómo debía ejercerlo a través de las leyes sancionadas por la divinidad, se colegía que cualquier innovación, cualquier reforma que modificara la perfecta forma de la sociedad, era peligrosa.

Para evitar que esas ideas nuevas, esas innovaciones, se divulgaran y pudieran poner en peligro a la sociedad, era necesario que un estricto sistema de censura fuera instituido. La libertad de pensamiento no implicaba, según Bonald, el derecho a diseminar errores, y la tolerancia con el error era sólo signo de indiferencia o de ignorancia. Cuanto más ilustrada era una sociedad, y más cercana se hallaba de la verdad, menos tolerante debía ser, y, por tanto, también «el hombre más ilustrado será pues el hombre, sobre las opiniones, menos indiferente o menos tolerante; y el ser soberanamente inteligente debe ser, por una necesidad de la naturaleza, soberanamente intolerante con las opiniones». ${ }^{25}$

25 Ibid., vol. 3, p. 493. Sobre el tema de la tolerancia en Bonald véase también Klinck, The French counterrevolutionary theorist, pp. 142-143; McMahon, Enemies of the Enlightenment, pp. 131-132. 
Bonald aplicó a los judíos sus ideas sobre la tolerancia, negando su derecho a la ciudadanía si no se convertían previamente al catolicismo; y esto en un momento (1806) en el que Napoleón se debatía entre dar marcha atrás en el proceso de emancipación iniciado por la Asamblea Nacional en 1791 o mantener la dirección del cambio. ${ }^{26}$

Mostró la misma tolerancia con los musulmanes. El islam, en efecto, se percibía como un enemigo ancestral que, casi tan longevo como el judaísmo, había amenazado y perseguido a la Cristiandad desde hacía siglos. Una vez que el Imperio otomano había entrado en una crisis que finalmente resultaría irreversible, la sensación de amenaza había desaparecido, pero la mera existencia de una fe alternativa al cristianismo, y que resultaba ser la de una porción muy importante de la humanidad, era un reto al que «la verdad de Cristo» debía enfrentarse. El islam no se percibía ya como una amenaza, porque el Imperio otomano carecía de poder suficiente, pero se seguía considerando una fe falsa, una aberración, un error del que había que librar a los musulmanes si los europeos querían difundir por el mundo la civilización cristiana y verse libres de una vez y para siempre de esa espada de Damocles que pendía sobre ellos: la del resurgir del islam. Porque el islam se veía como un error, un insulto a Dios, pero también como un peligro que abocaba a sus creyentes al pecado, a la intolerancia y a la violencia contra los cristianos. En los textos que Bonald dedicó al tema a lo largo de los años lo dejó, como veremos, bien claro.

\section{En los años del Directorio}

Las primeras líneas que Bonald dedicó al islam se encuentran ya en Théorie du pouvoir (1796). Como se apuntó más arriba, se trata de su primera y más importante obra, escrita en plena Revolución Francesa, y destinada precisamente a destruir sus bases intelectuales y devolver a Dios el papel de legislador supremo que los filósofos ilustrados le ha-

${ }^{26}$ Sobre el proceso de emancipación de los judíos en la Francia revolucionaria y napoleónica véase Michel Winock, La France et les juifs: de 1789 á nos jours, Seuil, Paris, 2004, pp. 11-27; Pierre Birnbaum, L'aigle et la synagogue: Napoléon, les juifs et l'état, Fayard, París, 2007. Sobre la actitud de Bonald hacia los judíos, véase Bonald, Oeuvres complètes, vol. 2, pp. 933-948; Arnold Ages, «Bonald and the Jews», Revue de l'Université d'Ottawa, vol. 44, n. 1 (1974), pp. 32-43. 
bían quitado para dárselo al hombre. En ella, Bonald trataba de mostrar que la sociedad civil estaba constituida por la unión de la sociedad política y la sociedad religiosa, y que sólo de la unión de la sociedades política y religiosa perfectas - aquellas instituidas por Dios en forma de monarquía absoluta y catolicismo respectivamente-, podía nacer la sociedad civil perfecta.

La primera parte de la obra, dedicada al poder político, estaba destinada a demostrar que sólo la monarquía absoluta de derecho divino era la sociedad política perfecta. En cambio, la segunda parte de la obra, la dedicada al poder religioso, estaba destinada a tratar de demostrar que sólo el catolicismo tenía la capacidad de constituir una sociedad religiosa perfecta $-\mathrm{y}$ por su asociación indisoluble con la monarquía absoluta, una sociedad civil perfecta-, acorde con las leyes de la naturaleza, con el orden establecido por Dios. Una sociedad construida sobre otras bases se vería necesariamente abocada al caos, la tiranía y el despotismo. ${ }^{27}$

Dentro de esa segunda parte, en el libro quinto, dedicado a utilizar la historia de la religión como prueba para demostrar la verdad del cristianismo católico - y su carácter de única constitución necesaria de la sociedad religiosa - y tras unas líneas destinadas a ensalzar las cruzadas como una causa santa, Bonald insertó un capítulo entero dedicado al «mahométisme». ${ }^{28}$ La razón para insertar un capítulo sobre tal tema es clara: en el más puro estilo de la polémica antiislámica medieval, Bonald utilizaba la denigración del islam - así como la del judaísmo y la del cristianismo evangélico-, para tratar de probar que la única religión verdadera era el catolicismo, dado lo despreciables que resultaban las demás religiones. Sin embargo, aunque la verdad del catolicismo debiera ser la conclusión de la argumentación — resultado lógico del examen que Bonald se disponía a realizar-, en realidad era una premisa indemostrada, explícitamente afirmada desde el principio, que guiaba toda la argumentación.

Efectivamente, según Bonald existían religiones de sentimiento y religiones de opinión. Las primeras eran religiones del sacrificio, del amor, las segundas del capricho y de la lujuria. Sólo el cristianismo católico era una religión de sentimiento perfecta. El judaísmo también era una religión de sentimiento, solo que imperfecta. El islam, por el contrario, era una re-

27 Bonald, Oeuvres complètes, vol. 1, pp. 451-453.

${ }^{28}$ Ibid., vol. 1, pp. 598-604. 
ligión de opinión. En realidad, no era propiamente una religión, sino más bien una filosofía, sin sacrificio, sin amor. Era, de hecho, el producto de la mente de «un impostor, de un genio audaz y de costumbres voluptuosas», que «hizo adoptar al pueblo más grosero las opiniones más absurdas». Mahoma simplemente acomodó las creencias judías y cristianas a «las costumbres sensuales de sus seguidores», prometiéndoles una vida futura de placeres y permitiéndoles una vida licenciosa. ${ }^{29}$

Era esa permisividad hacia la voluptuosidad, además de la fuerza de las armas - el terror - , lo que explicaba la expansión del islam: con «la cimitarra en una mano, el Corán en la otra, los hijos de Ismael, acostumbrados al robo, se expandirán entre sus vecinos, los saquearán, los convertirán, o los exterminarán». Así se difundirá el islam en Asia, sometiendo a esos «pueblos ardientes y débiles» a la opresión de su gobierno y su religión. ${ }^{30}$

Bonald aseguraba que la verdad de una religión se medía en función de sus efectos. Así, sorprendentemente afirmaba que, mientras los pueblos europeos dejaron de ser conquistadores cuando adoptaron el cristianismo, ${ }^{31}$ los musulmanes se volvieron conquistadores al adoptar el islam. Eso, según él, daba una idea del carácter de ambas religiones: la primera, una religión del amor, pacífica; la segunda, una religión del terror, violenta. El islam era, en definitiva, «la religión más opresiva», y el gobierno fundado sobre su ley, el «más destructor». ${ }^{32}$ Comparar ambas religiones resultaba, por todo ello, absurdo, como lo era, nos decía Bonald, comparar a Moisés con Mahoma, como algunos autores habían hecho, porque era como comparar «el original a la copia». Pero no sólo eso, al comparar los efectos de las leyes que dieron el uno y el otro se comprobaba cuál era el carácter de cada una de ellas. Así, el islam, «fundado sobre la conquista, no subsiste más que mediante la ayuda del imperio». Sólo cuando el islam estaba apoyado por la fuerza del Estado, subsistía. Allí donde los musulmanes eran sometidos a un poder político cristiano, abandonaban su religión, porque, según Bonald, «una religión de opinión resiste la persecución religiosa, (...); pero cede a la persecución política,

${ }^{29}$ Ibid., vol. 1, p. 598.

${ }^{30}$ Ibid.

${ }^{31}$ Como se comprenderá, cuando Bonald habla de cristianismo se refiere, en general, al catolicismo exclusivamente. Entiéndase así en lo sucesivo, salvo que se indique lo contrario.

32 Ibid., vol. 1, p. 599. 
es decir, a la privación de ciertas ventajas políticas». ${ }^{33}$ En cambio, con los cristianos no podía pasar nada de eso, porque «una religión de sentimiento o de amor no cede ni a la persecución política, ni a la persecución religiosa». ${ }^{34}$ «El cristiano», según Bonald, no abandonaba jamás su religión para adoptar otra, ni siquiera en condiciones de persecución política o religiosa, salvo para caer en el ateísmo. El cristianismo era, recordemos, una religión perfecta, dada por Dios. Por tanto, estaba en la naturaleza del hombre ser cristiano, o tender hacia el cristianismo cuando se creía en una religión imperfecta, porque «en todos los géneros, lo que es imperfecto tiende necesariamente a la perfección». Eso explicaba, aseguraba Bonald, que los pueblos paganos se convirtieran fácilmente al cristianismo; y explicaba también, por medio de la razón, el dogma de fe de la conversión futura de los judíos. ${ }^{35}$

Más abajo, Bonald volvía a la misma cuestión cuando trataba de mostrar que cualquier comparación entre Jesús y Mahoma era absurda; y esto, de nuevo, debido a los efectos que habían tenido cada una de las religiones que fundaron, así como las sociedades basadas en ellas. A partir de las diferencias existentes entre una sociedad caricaturizada con los peores rasgos y otra idealizada como encarnación de todo lo bueno y deseable, se establecía la imposibilidad de la comparación entre sus respectivos fundadores: «¿Qué tienen en común, de hecho, el débil imperio de esos esclavos, que no tiene otros recursos que nuestras divisiones, ni otra defensa que la peste, con la prosperidad, los progresos, la fuerza siempre creciente de las sociedades libres y cristianas?». El gobierno turco no se podía comparar tampoco con los gobiernos cristianos europeos, porque, de hecho, no era ni siquiera una monarquía propiamente dicha, ya que la monarquía era la constitución política dada por Dios al hombre, y el islam, siendo una religión falsa, no podía dar forma a una monarquía. Su gobierno era contrario a Dios, contrario a la naturaleza, y, por tanto, despótico. ${ }^{36}$

Por todo lo dicho, se deducía que el islam sólo subsistía por el terror, por el apoyo de un estado despótico y cruel, y una vez que ese poder terrenal desapareciera, desaparecería el islam:

\footnotetext{
33 Ibid., vol. 1, p. 600.

${ }^{34}$ Ibid.

35 Ibid., vol. 1, pp. 600-601.

36 Ibid., vol. 1, p. 603.
} 
Si se levantara en Oriente un poder cristiano, el islam no subsistiría ni un siglo; porque esa religión, puramente de opinión, no tiene otro poder conservador que el poder político, y en ella todo es contrario a la naturaleza de Dios y a la naturaleza del hombre. El Imperio otomano, dependiente como son todas las sociedades no constituidas, no se sostiene más que por el sistema general de Europa. ${ }^{37}$

Así, el fin del Imperio otomano era pura necesidad. Subsistía aún por los manejos de las potencias europeas, pero estaba intrínsecamente destinado a desaparecer, por su propia imperfección, por estar fundado sobre una religión contra natura. Era pura barbarie, y sólo podía ser destruido. No había reforma posible. El islam sólo podía ser civilizado si dejaba de ser el islam:

En su estado de ignorancia y de barbarie, no puede luchar contra las naciones civilizadas, ni civilizarse sin renunciar a sus opiniones religiosas. Será por tanto destruido, y su destrucción está en la naturaleza de las cosas, porque la civilización está en la naturaleza de la sociedad. ${ }^{38}$

Las esperanzas de Bonald parecían estar puestas en Rusia, en que Catalina la Grande - quien moriría ese mismo año de 1796 - propiciara la unión entre las iglesias de oriente y occidente y acabara conquistando el Imperio otomano, volviendo a establecer un poder cristiano en Constantinopla. Por esa razón, Bonald trataba de tranquilizar a los franceses acerca de los posibles inconvenientes que tendría para Francia una futura invasión rusa del Imperio otomano. Según Bonald, las naciones europeas deberían dejar de mirar por sus intereses particulares, y así verían que el fin del Imperio otomano era algo de interés general para la causa de la civilización y del catolicismo. Además, sostenía Bonald, una de las causas de los males de Francia estaba en la alianza que Francisco I había establecido con la Puerta. Así que no era del fin del Imperio otomano de lo que cabía esperar perjuicios para Francia, sino de su alianza con él..$^{39}$

En esas páginas se resumían las ideas que Bonald expondría años más tarde de forma más detenida acerca del carácter contra natura de la reli-

\footnotetext{
37 Ibid., vol. 1, p. 602.

38 Ibid.

39 Ibid., vol. 1, p. 603.
} 
gión islámica, la incapacidad del mundo islámico para progresar y constituir una verdadera civilización, dada su constitución errónea, acerca de la inevitabilidad de la decadencia otomana, y la necesidad de que las potencias cristianas, unidas, pusieran punto y final a esa ofensa a Dios y a la Razón que era el islam.

\section{En los años del Consulado}

El segundo texto que Bonald dedicó al islam y al mundo islámico, incluido en sus «Discursos políticos sobre el estado actual de Europa», ${ }^{40}$ fue escrito en un contexto bastante diferente. Aunque Bonald no es claro al respecto, es posible deducir del texto que fue escrito a finales de 1801 . Francia se hallaba entonces al final de la guerra contra la «Segunda Coalición» (1798-1802) encabezada por Gran Bretaña, Austria y Rusia. Seguramente ya se habían firmado, el 1 de octubre de 1801, los preliminares del tratado de Amiens; y, lo que es más importante para lo que aquí nos ocupa, la expedición a Egipto, iniciada en 1798, ya había fracasado totalmente.

A pesar de su fracaso, la expedición napoleónica al Egipto otomano regido por los mamelucos marcaría de forma indeleble la historia de Oriente Medio. Se trataba de la primera vez desde las cruzadas que un ejército europeo se instalaba en la zona, estableciendo allí un efímero gobierno. La expedición marcaría el inicio del colonialismo europeo, y para muchos historiadores marcaría también el inicio de la Edad Contemporánea en el mundo árabe. ${ }^{41}$ Para Napoleón y los militares y científicos que le acompañaron, la expedición era el primer paso para llevar la civilización, encarnada en la Francia republicana, a Oriente. ${ }^{42}$ Para Bonald, por el contrario, todo intento de llevar la civilización a un país musulmán que no pasara por su previa conversión al catolicismo, es-

40 Parece ser que el texto fue escrito para ser publicado en el Mercure de France, pero finalmente apareció en el tercer y último volumen de Législation primitive, Le Clere, París, 1802, pp. 108 y ss.

41 Juan Cole, Napoleon's Egypt: invading the Middle East, Palgrave Macmillan, New York y Basingstoke, 2007; Bárbara Azaola Piazza, Historia del Egipto contemporáneo, Catarata, Madrid, 2008, p. 14.

42 Cole, Napoleon's Egypt; Patrice Gueniffey, Bonaparte: 1769-1802, Harvard University Press, Londres y Cambridge, 2015, p. 449. 
taba destinado al fracaso. La expansión de la civilización sólo vendría con la destrucción del islam y su sustitución por la única religión verdadera. Pero la expedición había fracasado, y Bonald se lamentaba de que Egipto no hubiera permanecido en manos francesas, de que no se hubiera introducido en el país la religión católica, «y con ella todas las instituciones bienhechoras».43

Pero para Bonald la expedición de Egipto significaba algo más: era una muestra de la evidente debilidad del Imperio otomano, un presagio de su inminente destrucción; de la destrucción del islam en general, que sucumbiría una vez que el poder político otomano desapareciera. Es eso lo que Bonald veía.

Según él, un Estado basado en la religión islámica no podía ser más que un Estado bárbaro. La civilización sólo podía tener su origen en el cristianismo, y la misma superioridad técnica, militar y económica de los Estados europeos cristianos demostraba que esto era así. Y no sólo eso, la superioridad europea demostraba también que el cristianismo era la verdadera religión. Al contrario, la situación de decadencia del Imperio otomano demostraba la falsedad del islam. A ojos de Bonald, el islam era «la única causa de la irremediable debilidad del imperio otomano, como el cristianismo es el verdadero principio de la fuerza siempre creciente de la sociedad cristiana; pues a la larga no hay nada tan fuerte como la verdad y tan débil como el error». ${ }^{44}$ Así, la decadencia otomana era irremediable, pues tenía su causa primera en la base sobre la que se sustentaba su sociedad, en lo que Bonald llamaba su «constitución». Una religión falsa no podía dar como resultado una civilización, sino sólo barbarie.

Además de ser una religión falsa y germen de la barbarie más absoluta, el islam era lo contrario del cristianismo. Mientras el cristianismo promovía la paz, el islam promovía la violencia; mientras el cristianismo comenzaba por convertir a los hombres por la palabra, y sólo después se apoderaba del Estado, el islam se apoderaba primero del Estado por la violencia y luego convertía a los hombres gracias a ese poder. ${ }^{45}$ Por esta razón, la historia de las relaciones entre el islam y la Cristiandad había sido siempre de enfrentamiento. El islam siempre había atacado a la Cristiandad, hasta que ésta pudo detenerlo e incluso responder. Las cruzadas,

\footnotetext{
43 Bonald, Oeuvres complètes, vol. 2, pp. 379-380.

44 Ibid., vol. 2, p. 443.

45 Ibid., vol. 2, p. 446.
} 
en este sentido, estuvieron guiadas por «un principio de humanidad», y fueron una empresa legítima, pues «salvaron a Europa, y a la civilización con ella, de la barbarie musulmana». ${ }^{46}$

Siendo el islam el enemigo secular de la Cristiandad, no era extraño que se aliase con otros de sus enemigos para atacarla. La Reforma luterana, por ejemplo, entró, según Bonald, en connivencia con los musulmanes desde que surgió, pues desde su nacimiento el luteranismo había establecido una alianza con los enemigos del catolicismo. El acercamiento entre islam y luteranismo se había visto facilitado por la comunión de intereses - acabar con el catolicismo-, pero también por la comunión que existía entre ambas concepciones religiosas. Ambas eran, según Bonald, formas de deísmo: el fatalismo del islam recordaba a la predestinación de los luteranos, «y el divorcio permitido por Lutero no difiere en el fondo de la poligamia sancionada por la ley de Mahoma». ${ }^{47}$

Pero el final de ese conflicto secular estaba por llegar, pues el Imperio otomano no podría reponerse del estado en el que se encontraba. Mientras los europeos habían avanzado, los turcos se habían quedado estancados, y la razón de ello había que buscarla, de nuevo, en el Corán y las enseñanzas de Mahoma. Así, contradiciendo a Condorcet - que sostenía que, a pesar de las enseñanzas simples, sabias y tolerantes del Corán, los musulmanes vivían en un estado de «intolerable barbarie»-, Bonald repetía que de una doctrina religiosa buena no podía nacer una sociedad bárbara, así como de una doctrina falsa, una sociedad civilizada. Por lo tanto, «la incurable estupidez de los mahometanos» tenía su origen y causa en la doctrina religiosa que profesaban. La falsedad del islam tenía su reflejo en las sociedades islámicas, en su forma de vida, en sus leyes, en su gobierno: «entre los turcos, como entre todos los pueblos mahometanos, todo es vicioso, absurdo, opresivo, constitución y administración; constitución religiosa, constitución familiar, constitución de Estado, administración de la paz, administración de la guerra, política exterior y régimen interior». ${ }^{48}$ Era pura barbarie. El despotismo, la poligamia, el fanatismo, el fatalismo, todo era signo de barbarie y remitía a la falsedad del islam. ${ }^{49}$ Y esto seguiría siendo así mientras la base religiosa de su sociedad fuera el islam; pues sólo en el cristianismo católico, recalcaba Bonald, estaba la

\footnotetext{
${ }^{46}$ Ibid., vol. 2, pp. 452-453.

47 Ibid., vol. 2, pp. 459-460.

48 Ibid., vol. 2, p. 462.

49 Ibid., vol. 2, pp. 462-464.
} 
civilización: el progreso de una nación «es el resultado de la civilización, lejos de ser su comienzo. El islam condena a los turcos a una incurable estupidez, y es por la religión, y no por la geometría, por lo que comienza la civilización». ${ }^{50}$

Puesto que el derecho de las potencias europeas a intervenir en el Imperio otomano se basaba en su legitimidad - entendida como conformidad de sus sociedades con los mandatos divinos - , y puesto que la ilegitimidad de la sociedad islámica se basaba en estar fundada en preceptos contrarios a la Ley de Dios, la lucha contra el islam adquiría tintes sagrados: se trataba de la lucha de la ciudad de Dios contra los enemigos de Dios. No es extraño, por tanto, que el modelo que Bonald tenía en mente a la hora de hablar de la intervención armada contra el Imperio otomano fueran las cruzadas.

Efectivamente, Bonald presagiaba una vuelta a las cruzadas en un futuro no muy lejano. Desde su punto de vista, dado que la decadencia islámica no tenía solución, el fin de la presencia otomana en Europa estaba cercano. Perderían Grecia y Constantinopla volvería a manos cristianas. Esto quizás hiciera que en cierto momento los turcos quisieran volver a recuperarla, por lo que no sería extraño, decía Bonald, que «nuestros descendientes estén destinados a ver, para escándalo de la filosofía moderna, nuevas cruzadas de cristianos, ya para atacar a los mahometanos, ya para defender contra ellos al imperio griego, el más expuesto a su insulto». ${ }^{51}$

Una vuelta a las cruzadas sería un golpe de muerte para el islam. De hecho, según Bonald, era muy probable que los griegos llegaran a conquistar Asia Menor y los turcos fueran devueltos a un rincón de Asia. Allí entrarían en conflicto con Irán y este conflicto sería aprovechado por Rusia para dar «un golpe mortal a la religión mahometana». Incluso «si los europeos se establecen en las cercanías del Mar Rojo, un día algunos aventureros irán a saquear las inmensas riquezas de la tumba del profeta, que no está más que a veinticinco leguas del mar, lo que causará una gran perturbación en todo el islam». ${ }^{52}$ En definitiva, el triunfo de la civilización contra la barbarie, que era al fin y al cabo el triunfo de la Cristiandad sobre el islam, estaba cercano.

\footnotetext{
50 Ibid., vol. 2, p. 469, cursivas en el original.

51 Ibid., vol. 2, p. 470.

52 Ibid., vol. 2, p. 470-471, nota 473.
} 


\section{En los años de la Restauración}

Años después, Bonald volvería al mismo tema en un artículo y dos cartas al editor que fueron publicados en el Journal des débats entre septiembre y noviembre de 1821. Entonces el contexto era muy diferente. Consolidada ya la Restauración borbónica, muchos intelectuales franceses, como otros muchos europeos, vivían pendientes de lo que ocurría en los Balcanes.

A principios de 1821 estalló una revuelta en la Morea liderada por un grupo de nacionalistas griegos, la cual se extendió rápidamente a las islas del Egeo. La consiguiente reacción otomana, y el estancamiento de la situación en una guerra que duraría casi diez años, provocó una reacción filohelénica en toda Europa. Intelectuales como Lord Byron, Chateaubriand, Benjamin Constant o Percy Shelley, escribieron en defensa de los rebeldes griegos y pidiendo la intervención de las potencias europeas en su favor. ${ }^{53}$ Bonald, aunque de manera breve, no dejó de ocuparse del tema para volver a retomar sus ya conocidas ideas acerca del islam.

En sus textos de 1821 Bonald trató de defender la revuelta griega argumentando que el gobierno otomano en Grecia era ilegítimo. Lo era por dos razones. En primer lugar, porque estaba basado en el sometimiento por la fuerza, en la tiranía, en la continua subyugación de un pueblo que se había mantenido siempre separado de sus dominadores, manteniendo intactas su religión, su lengua y sus costumbres. Esa diferencia insalvable entre turcos y griegos había derivado en una hostilidad perpetua - «hay hoy, y ha habido siempre, hostilidad permanente entre los turcos y los griegos, considerados como naciones»- . Esa hostilidad hacía imposible la convivencia, impedía la paz, y el gobierno legítimo, decía Bonald, «supone el estado de paz, de libertad civil, de igualdad política entre el pueblo que posee y el pueblo que es poseído», pero eso nunca había existido entre turcos y griegos. Los griegos eran esclavos, no disfrutaban de igual-

53 Sobre la reacción intelectual europea ante la revuelta griega véase Frédérique Tabaki-Iona, «Philhellénisme religieux et mobilisation des Français pendant la révolution grecque de 1821-1827», Mots. Les Langages du Politique, n. 79 (2005), pp. 47-59; Nere Basabe, Del Imperio a la Federación: la idea de Europa en Francia, 1800-1848, Tesis Doctoral, Facultad de Ciencias Políticas y Sociología, Universidad Complutense de Madrid, Madrid, 2009, pp. 301-328; Roderick Cavaliero, Ottomania: the romantics and the myth of the Islamic Orient, I. B. Tauris, Londres, 2010, pp. 97-112. 
dad de derechos, eran excluidos del poder, lo que impedía la unión de ambos pueblos. ${ }^{54}$

Pero, en segundo lugar, había algo mucho más importante, una legitimidad que sólo venía dada por Dios, una legitimidad que estaba ausente en el gobierno islámico, dado que estaba basado en una religión falsa. Por lo tanto, cualquier revuelta contra ese poder ilegítimo, tiránico, despótico, resultaba totalmente legítima. De hecho, Bonald legitimaba igualmente la intervención armada extranjera en el Imperio otomano, e incluso la colonización europea en el mundo islámico. Expandir la civilización cristiana, librar a los pueblos cristianos sometidos al poder despótico otomano y librar a los mismos musulmanes del estado de barbarie en el que vivían, era, según Bonald, un deber. Tal intervención sería, además, legítima, porque, como hemos dicho, el gobierno otomano era totalmente ilegítimo:

Pero hay otra legitimidad, y más sagrada que cualquier otra, la de la razón y la verdad. Toda sociedad que, por culpa de sus leyes, no puede conducir a los hombres a su perfección moral; toda sociedad que, como la de los turcos, condena a sus pueblos a una inmutable estupidez (es Condorcet quien lo dice); toda sociedad en la que las leyes son contrarias a la naturaleza del hombre y de la sociedad, donde la religión es absurda, donde las prácticas son bárbaras y licenciosas, no es una sociedad legítima, pues no es conforme a los mandatos del padre y autor de toda sociedad. ${ }^{55}$

Se trataba, por lo tanto, de un gobierno basado en una ley falsa que, por eso mismo, era incapaz de elevar a su pueblo a un estado de civilización, incapaz de «conducir a los hombres a la virtud y la felicidad», lo que lo convertía en ilegítimo. Todo ello se debía, como hemos visto tantas veces, a que se trataba de un gobierno que no se basaba en el catolicismo: «el estado legítimo de la sociedad es la civilización, pues es su estado natural, y la civilización no es más que el cristianismo aplicado al estado social». 56

${ }^{54}$ Bonald, Oeuvres complètes, vol. 2, p. 909. Esta reivindicación de la igualdad de derechos en boca de un defensor del Antiguo Régimen resulta curiosa, y es representativa del doble rasero con el que los autores antiislámicos suelen juzgar lo que sucede en el mundo islámico.

55 Ibid., vol. 2, pp. 909-911, cursivas en el original.

56 Ibid., vol. 2, pp. 909-912. 
Pero si los turcos trataban mal a los griegos, esto también se debía a que su religión les impedía tener relaciones amistosas con los cristianos. No podía haber entre musulmanes y cristianos ni siquiera afinidad política. Los musulmanes eran enemigos de los cristianos y sólo podían sentir hacia ellos un «odio religioso». Eso impedía cualquier afinidad y abocaba a cristianos y musulmanes a un enfrentamiento insoslayable. El Imperio otomano era, por tanto, un Estado enemigo del cristianismo, de la Europa cristiana, que sometía a un pueblo cristiano a esclavitud. Ese pueblo se había levantado legítimamente contra su opresor. Estaba claro, por tanto, de qué lado debían situarse las potencias europeas.

El artículo de Bonald recibió una respuesta por parte del escritor Achille Jouffroy, en la que, entre otras cosas, señalaba que las ideas de Bonald sobre la legitimidad de la revuelta contra un gobierno tildado de extranjero servían igualmente para legitimar cualquier levantamiento popular contra el gobierno de otros imperios plurinacionales, como el Habsburgo. De hecho, servía para legitimar cualquier levantamiento contra el gobierno: bastaba con argumentar que la casta dirigente era extranjera. ${ }^{57}$

En su respuesta, Bonald volvía a repetir las ideas expresadas su texto de 1801 sobre el estado político de Europa: la idea de que los luteranos, los deístas y los musulmanes tenían en común su idea de Dios, y de que existía un parecido entre la Reforma y el islam - opinión que, decía, también sostenía Maistre - . Volvía también a defender las cruzadas, y concedía que, después del fracaso del último asedio a Viena, los turcos se habían vuelto menos peligrosos. Pero eso era algo circunstancial, según Bonald, y que no debía hacer que la Europa cristiana bajara la guardia, pues «es fácil de ver que su ferocidad natural y su orgullo bárbaro no están más que suspendidos, y que retomarán su curso a la primera ocasión». .8

En respuesta directa a la objeción expuesta por Jouffroy, Bonald sostenía que lo principal en la legitimación de la revuelta no era que el gobierno fuera extranjero; lo principal era que ese gobierno fuera ilegítimo porque gobernaba con arreglo a leyes faltas de razón, aberrantes, falsas. Así que cuando un gobierno militar extranjero gobernaba con arreglo a la razón, es decir, con arreglo a las leyes morales cristianas, entonces ese gobierno militar era legítimo.

${ }^{57}$ La respuesta de Jouffroy fue publicada en el Journal des Dèbats el 23 de septiembre de 1821 , p. 3 .

58 Bonald, Oeuvres complètes, vol. 2, p. 915. 
Así, en la segunda parte de su carta a Jouffroy, publicada en el mismo periódico el día 8 de noviembre de 1821, Bonald, siguiendo esa línea argumental, llegaba a legitimar el gobierno colonial - católico, se entiende - sobre los musulmanes como el más noble deber que un pueblo podía tener: el deber de extender la verdad por el mundo y acabar con el error, la barbarie, el Mal. Sostenía, de hecho, que un pueblo tenía el deber de obligar a otro a abandonar sus costumbres cuando éstas resultaban aberrantes:

Y puesto que me pregunta si, bajo el pretexto de la ilegitimidad de sus leyes, podríamos atacarles [a los pueblos bárbaros], le respondería que, si fuéramos sus vecinos, el más noble uso que podríamos hacer de nuestras fuerzas y nuestras luces sería el de obligarles a renunciar a sus costumbres abominables: la fuerza no se ha dado a las naciones cristianas más que para difundir los beneficios de la civilización..$^{59}$

En definitiva, no existía ilegitimidad en el gobierno de un pueblo extranjero sobre otro cuando aquél lo hacía para extender los beneficios de la civilización - es decir, del catolicismo-. En tal caso, se convertía en un bien para el pueblo sometido y en un deber. En cambio, si el dominio era ejercido por un pueblo que no tenía con él la verdad y la civilización - es decir, que no era católico-, entonces ese dominio era ilegítimo y debía ser destruido. Mientras el empleo de la fuerza para expandir el islam era, según Bonald, una aberración, el empleo de la fuerza para expandir el catolicismo era un beneficio para la humanidad, un deber insoslayable. La legitimidad para ejercer la fuerza y para establecer una forma legítima de gobierno sólo estaba en el catolicismo, pues era el único depositario de la verdad, de la razón, el único agente de civilización, la encarnación del Bien.

\section{En los años posteriores}

La visión que Bonald tenía del islam tuvo una influencia clara en autores posteriores. Sus ideas sobre la ilegitimidad del gobierno islámico en general, y, en particular, del gobierno otomano en los Balcanes, influirá,

59 Ibid., vol. 2, p. 921. 
por ejemplo, en algunos intelectuales rusos deseosos de legitimar la intervención del Imperio de los zares en la zona. ${ }^{60}$ Pero parece que tuvieron más trascendencia sus ideas acerca de la incapacidad del islam como religión para sobrevivir sin un gobierno que la apoyase; y, por consiguiente, sobre la destrucción del islam como religión una vez que el gobierno sobre el que se apoyaba desapareciera. También sus ideas sobre la necesidad de la destrucción del islam como precondición para la expansión de la civilización tuvieron un importante eco. Esas ideas influyeron sin duda en Ernest Renan, quien en 1862 afirmaría que:

En esta hora, la condición esencial para que la civilización europea se expanda, es la destrucción de lo semítico por excelencia, la destrucción del poder teocrático del islam, por consecuencia la destrucción del islam; pues el islam no puede existir más que como religión oficial; cuando se le reduzca al estado de religión libre e individual, perecerá. ${ }^{61}$

Evidentemente, Renan y Bonald no habrían estado de acuerdo acerca de en qué consistía la civilización, ni en qué hacía del islam un impedimento para ésta. El pensamiento de Renan en este punto podría considerarse una secularización del de Bonald. Renan, efectivamente, no compartía el marco confesional en el que Bonald basaba todo su pensamiento, y consideraba que lo que hacía que el islam fuera un impedimento para el progreso de la civilización era su carácter semítico.

Más en consonancia con el marco conceptual confesional de Bonald, y con sus ideas acerca del islam y la civilización, estuvieron los clérigos, intelectuales y publicistas católicos franceses que, especialmente durante la segunda mitad del siglo XIX, defendieron una visión de la colonización francesa en el mundo islámico diferente a la de los republicanos. Para ellos, la mission civilisatrice en el mundo islámico debía comenzar por la conversión de los musulmanes. Sin esa conversión previa, la civilización nunca penetraría en las colonias francesas en el mundo islámico y los musulmanes seguirían siendo enemigos acérrimos de los cristianos, un peligro constante para el dominio colonial francés. Por esa razón, presionaron

60 Victor Taki, «Orientalism on the margins: the Ottoman empire under Russian eyes», Kritika: Explorations in Russian and Eurasian History, vol. 12, n. ${ }^{\circ} 2$ (2011), pp. 321-351.

${ }^{61}$ Ernest Renan, De la part des peuples sémitiques dans l'histoire de la civilisation, Michel Lévy Fréres, París, 1862, p. 27. 
incansablemente a las autoridades coloniales francesas para que apoyaran decididamente la empresa de proselitismo iniciada por las misiones católicas, lo cual originó varios conflictos. ${ }^{62}$

Renan y los misioneros católicos compartían, desde posicionamientos muy distantes, el mismo diagnóstico acerca de la necesidad de acabar con el islam como requisito previo para la expansión de la civilización. Era necesario hacer que los musulmanes abandonaran su religión. En palabras del propio Renan: «emancipar al musulmán de su religión es el mejor servicio que le podemos hacer».$^{63} \mathrm{Sin}$ embargo, los misioneros y Renan no se habrían puesto de acuerdo sobre qué se entendía por «emancipar al musulmán de su religión». Para los primeros, significaba adoptar el catolicismo. Para el segundo, significaba adoptar el credo republicano. Bonald, por su parte, lo había tenido muy claro.

La idea de la incompatibilidad del islam con la civilización y sus avances, tan central en Bonald, será un lugar común en buena parte del pensamiento europeo durante los siguientes doscientos años. Ya fuera desde las posturas más confesionales o desde las más laicistas -y partiendo de presupuestos diferentes en cuanto a las causas de la incompatibilidad, y llegando a conclusiones diferentes en cuanto a qué debía hacerse para remediarlo-, buena parte de los intelectuales europeos seguirá manteniendo que el islam es incompatible con el progreso de la civilización y que, en el interés de ésta, su destrucción resulta ser una necesidad.

Por su puesto, esto no quiere decir que la visión que los europeos han tenido del islam en época contemporánea pueda resumirse en esos dos grandes grupos. Si bien es posible que ambos han podido disfrutar de una suerte de hegemonía intelectual al respecto, no es menos cierto que han seguido existiendo otras formas de percibir el islam, otras que a Bonald le habrían parecido directas herederas de la actitud que, a su parecer, los filósofos ilustrados habían mostrado hacia esa religión, esa "predilección» que tanto le molestó y contra la que tanto luchó.

62 Sobre estas ideas véase Marcel Émerit, «Le problème de la conversion des musulmans d'Algérie sous le Second Empire: le conflict entre Mac-Mahon et Lavigerie», Revue Historique, n. 223 (1960), pp. 63-84; Bertrand Taithe, «Algerian orphans and colonial Christianity in Algeria, 1866-1939», French History, vol. 20, n. ${ }^{\circ} 3$ (2006), pp. 240-259; Fernando Bravo López, «"El Diablo entre los musulmanes”: Islamofobia y antimasonismo en la Francia de fin de siglo a la luz de la obra de Julien Rouquette», Historia y Política, n. 31 (2014), pp. 225-253.

63 Ernest Renan, Discours et conférences, Calmann-Lévy, París, 1887, p. 407. 


\section{Conclusión}

El trabajo de los autores contrarrevolucionarios fue clave en la supervivencia del pensamiento reaccionario en un momento en el que éste parecía sucumbir ante el avance imparable de la Ilustración y la Revolución. Lo actualizó, armándolo con el lenguaje y las formas del pensamiento filosófico ilustrado, pero manteniendo el fondo intacto. Lo llevó así al siglo XIX, y permitió su pervivencia hasta mucho después, dotando a los políticos y publicistas más conservadores de las armas dialécticas adecuadas para su lucha contra el liberalismo rampante.

Los pensadores contrarrevolucionarios desempeñaron el mismo papel en la transmisión de la tradición antiislámica y en la lucha contra la supuesta predilección que, según ellos, los ilustrados habían sentido hacia el islam. Trataron de reedificar los muros derribados por algunos ilustrados y situar a los musulmanes donde, a su juicio, debían estar: en el lado de la irracionalidad, la perversidad, la lujuria y la maldad; bien separados de los cristianos, bien diferenciados, para que no cupiera la menor duda de dónde estaba el Bien y dónde el Mal. En definitiva, lucharon contra las «mentiras» de los philosophes en un intento denodado por reinstaurar la «verdad».

Bonald, en este sentido, nos ha servido como un ejemplo claro de este papel bisagra desempeñado por los contrarrevolucionarios entre la tradición antiislámica anterior y los acercamientos antiislámicos contemporáneos. En las páginas que Bonald dedicó al islam se puede comprobar la influencia clave que la tradición antiislámica anterior tenía en su pensamiento: la identificación de los árabes como descendientes de Ismael; la descripción de Mahoma como «impostor», «voluptuoso», «vicioso», etc.; la descripción del Corán como receptáculo de absurdidades y herejías; la visión del islam como una religión falsa, violenta, impuesta por la fuerza de las armas y adoptada por pueblos pecadores debido a su permisividad y lubricidad; la visión de las cruzadas como guerras justas y como modelo a seguir por las potencias europeas a la hora de lidiar con el mundo islámico; etc.

En concreto, en su visión del gobierno islámico como ilegítimo, Bonald recogía un muy extendido argumento dentro de la tradición antiislámica anterior: la legitimidad de un gobierno dependía de su subordinación a la Ley de Dios, tal y como era interpretada por la Iglesia católica. Un gobierno que hacía caso omiso de la Ley, o que se guiaba por una ley falsa, era ilegítimo, y su derrocamiento resultaba legítimo y necesario. Esa línea de pensamiento la encontramos, por ejemplo, en obras del siglo XIII como la Historia de los árabes y la Historia de España del arzo- 
bispo Rodrigo Jiménez de Rada, así como en la Crónica General de Alfonso X. A partir de esas ideas, la guerra contra los reinos islámicos de la Península, y su conquista, quedaba legitimada. ${ }^{64}$ De la misma premisa Bonald sacaba las mismas conclusiones: el gobierno otomano era ilegítimo y su destrucción no sólo era legítima, sino necesaria. A la destrucción del Imperio otomano seguiría la de todos los demás gobiernos islámicos de la Tierra, lo que, en último término, ocasionaría la destrucción del islam como religión.

En buena medida, Bonald aplicaba al islam el mismo criterio que había aplicado a la Ilustración y la Revolución. La religión islámica era para el gobierno islámico lo que la Ilustración era para la Revolución. La religión islámica y la Ilustración habían apartado a los hombres de Dios, habían instituido unas creencias falsas y contra natura. Como resultado, habían instaurado unas formas de gobierno que no eran más que dos formas de despotismo, de tiranía, cuya destrucción resultaba legítima y necesaria: el gobierno islámico y el gobierno revolucionario. Tanto el islam como la Ilustración debían ser destruidos para que el caos fuera sustituido por el orden, para que el gobierno legítimamente sancionado por Dios volviera a regir el destino de los hombres, para que el Bien venciera al Mal.

Las páginas que Bonald dedicó al islam son también un ejemplo claro del método esencialista sobre el que se basa, y se ha basado históricamente, el discurso antiislámico o islamófobo. ${ }^{65}$ Bonald juzgaba a las personas a partir de las esencias «cristianismo», «judaísmo» o «mahométisme», y de las características que asociaba a cada una de ellas. Obviamente, no realizaba juicios parciales a partir de un estudio pormenorizado de los grupos de personas a los que juzgaba tan taxativamente. Realizaba juicios globales acerca de las personas - independientemente de cuál fuera su origen étnico, su educación, su clase social, o el lugar o momento histórico en el que hubieran vivido - en función únicamente de su identificación con una religión, con una esencia. Eran musulmanes, y su identificación con el islam bastaba para juzgarlos a todos y a cada uno de ellos. Bonald podía, por tanto, afirmar cualquier cosa sobre los musulmanes sin necesidad de probarlo a partir de dato empírico alguno. Todo se fun-

64 Véase John V. Tolan, Saracens: Islam in the medieval European imagination, Columbia University Press, Nueva York, 2002, pp. 185-189.

65 Sobre el esencialismo en la islamofobia y el antisemitismo véase Bravo López, En casa ajena, pp. 60-66. 
damentaba en la imagen preestablecida del islam que él tenía, en su mayor parte basada en la tradición antiislámica cristiana. Introducía citas de otros autores para sostener la imagen preestablecida o para refutar aquellas ideas que entraban en contradicción con esa imagen. Pero en cuanto a lo que él creía que era el islam y cómo eran los musulmanes, sólo tenía que enunciarlo: era así, y punto.

A la vez, en la obra de Bonald también se ve con claridad la influencia que en él tuvieron los autores ilustrados, especialmente Montesquieu, a quien citaba en repetidas ocasiones haciendo suyas sus palabras. ${ }^{66}$ Daba así muestra de estar de acuerdo con algunas de las cosas negativas que ciertos ilustrados dijeron acerca del islam, lo que contradecía su idea general de que éstos sintieron predilección por esa religión. Además de eso, Bonald adaptaba a sus necesidades el modo de argumentación filosófica de los ilustrados. Adaptaba su lenguaje y algunas de sus ideas para hacer que sus escritos estuvieran más acorde con los tiempos, aun cuando mantenía intacto el fondo de su pensamiento en defensa de los fundamentos confesionales del Antiguo Régimen. Un ejemplo claro de esta forma de proceder es cómo hacía uso del concepto de «civilización», tan inextricablemente unido en su origen al pensamiento ilustrado. ${ }^{67}$

La idea de civilización, como hemos visto a lo largo de este trabajo, era central en toda su argumentación, pero se trataba de un concepto basado en unos fundamentos muy diferentes a los del concepto ilustrado. Bonald lo había transformado. Se trataba de una idea de civilización construida sobre los cimientos de la religión. Era la religión católica, y únicamente la católica, la que daba forma a la civilización, la que la hacía posible. Era la religión católica la que daba una verdadera constitución a la sociedad civil perfecta, una sociedad basada en la unión indisoluble de la sociedad política perfecta - la monarquía absoluta - , y la sociedad religiosa perfecta - la Iglesia católica-. Era esa sociedad perfecta la única capaz de producir una civilización digna de ese nombre. Fuera de ella, todo era caos, despotismo y tiranía. Fuera de ella estaba el Mal.

Bonald, en definitiva, puso las bases del pensamiento antiislámico católico contemporáneo, adaptando a las necesidades de la Francia del si-

\footnotetext{
66 Véase, por ejemplo, Bonald, Oeuvres complètes, vol. 1, pp. 599 y 603.

67 Véase Juan R. Goberna Falque, Civilización: historia de una idea, Universidad de Santiago de Compostela, Santiago de Compostela, 1999.
} 
glo XIX la tradición antiislámica anterior. Gracias a su trabajo, en los años posteriores, los publicistas e intelectuales católicos preocupados por el papel de Francia en el mundo islámico tuvieron a su disposición un marco teórico a partir del cual defender su propia visión de la mission civilisatrice, y pudieron enfrentarla a la visión que defendían los republicanos laicistas. Gracias a Bonald, estuvieron en disposición de dar la batalla intelectual en favor de una colonización del mundo islámico explícitamente basada en la idea de la necesaria destrucción del islam. De esa destrucción dependía, a su juicio, el futuro de la única civilización digna de tal nombre: la católica. 